\title{
Analysis of Tumor Necrosis Factor and Lymphotoxin Secreted by Incubation of Lymphokine-activated Killer Cells with Tumor Cells
}

\author{
Hirofumi Naganuma, Ryoichi Kimura, Atsushi SASAKI, Hideaki NUKUI \\ and Kachio TASAKA*
}

Departments of Neurosurgery, and *Parasitology and Immunology, Yamanashi Medical College, Yamanashi

\begin{abstract}
This study investigated the secretion of a tumor necrosis factor (TNF) and lymphotoxin (LT) from lymphokine-activated killer (LAK) cells during co-culture with glioblastoma cell lines, autologous glioma cells, and other non-gliomatous tumor cell lines (K562 and Daudi). Cytokine secretion from peripheral blood mononuclear cells (PBMC) was also examined. The TNF activity of culture supernatants was measured by L cell cytotoxic assay, and a neutralization test using anti-TNF and/or anti-LT antibodies determined whether the cytotoxic activity was due to TNF or LT. The results show that LAK cells secrete both TNF and LT during monoculture and release increased amounts of TNF and LT with non-gliomatous tumor cell stimulation, but PBMC secrete only TNF with tumor cell stimulation. Glioblastoma or anaplastic astrocytoma cells, however, did not stimulate cytokine secretion from either LAK cells or PBMC. This indicates a discrepancy between the capability of LAK cells to lyse malignant glioma cells and cytokine secretion from LAK cells, and suggests that malignant glioma cells may produce some factors which inhibit cytokine secretion from LAK cells.
\end{abstract}

Key words: malignant glioma, tumor necrosis factor, lymphotoxin, lymphokine-activated killer cell

\section{Introduction}

Lymphokine-activated killer (LAK) cells kill a wide variety of tumor cells in vitro, ${ }^{14)}$ although the mechanism is not completely clear. Rosenberg et $a l .^{29,30)}$ proposed immunotherapy using LAK cells for patients with various cancers, finding LAK cell therapy was effective against some cancers resistant to drugs and/or irradiation. Recently, clinical trials using LAK cells have been conducted on malignant gliomas. ${ }^{16-18,31,38)}$ We reported a case which showed complete remission of recurrent glioblastoma multiforme following infusions of LAK cells. ${ }^{23)}$

LAK cells express messenger ribonucleic acid for interleukin (IL)- $1 \alpha$, IL-1 $\beta$, interferon (IFN)- $\gamma$, tumor necrosis factor (TNF), and lymphotoxin (LT), ${ }^{19 j}$ and secrete TNF, LT, and IFN $-\gamma .{ }^{9)}$ TNF and LT are related proteins secreted by macrophages and lym-

Received May 27, 1991; Accepted September 9, 1991 phocytes, respectively, which are important in the destruction of tumor cells and virally infected cells. ${ }^{2,25}$ IFN- $\gamma$ combined with TNF or LT displays a considerable synergistic effect in the suppression of tumor cell proliferation. ${ }^{21,33,34)}$

LAK cells are usually infused via an Ommaya reservoir in the treatment of malignant glioma patients. After infusion, the LAK cells may contact and kill tumor cells. How LAK cells secrete cytokines in contact with tumor cells, however, is not well understood. This study investigated the secretion of TNF and LT from LAK cells stimulated by malignant glioma cells and non-gliomatous tumor cells. For comparison, we also investigated cytokine secretion from peripheral blood mononuclear cells (PBMC).

\section{Materials and Methods}

I. Cell lines and tumor cells

Tumor cell lines were cultured at $37^{\circ} \mathrm{C}$ in a 
humidified $5 \% \quad \mathrm{CO}_{2}$ atmosphere in RPMI 1640 medium supplemented with $2 \mathrm{mM}$ glutamine, $100 \mathrm{U} /$ $\mathrm{ml}$ penicillin, $100 \mu \mathrm{g} / \mathrm{ml}$ streptomycin, $0.05 \mathrm{mM} \mathrm{2-}$ mercaptoethanol, and $10 \%$ fetal bovine serum. The following cell lines were used: T98G, A172 (human glioblastoma cell line), Daudi (human B tumor cell line derived from a Burkitt's lymphoma patient), K562 (human erythroleukemic cell line), L.P3 mouse fibroblast, and RPMI 1788 (human lymphoblastoid cell line). The cell lines other than L.P3 (donated by Dr. Y. Miyagawa, Dept. of Microbiology, Yamanashi Medical College) were obtained from the Japanese Cancer Research Resources Bank, Tokyo. LAK cells killed 64,70 , and $72 \%$ of T98G, Daudi, and $\mathrm{K562}$, respectively, at an effector/target ratio of $50 / 1$ in 4 -hour ${ }^{51} \mathrm{Cr}$-release assay. L.P3 cells were sensitive to both TNF and LT. RPMI 1788 cells produce LT."

Tumor cells obtained at surgery from two patients with anaplastic astrocytoma or low-grade astrocytoma were maintained in complete medium, and were used in the experiments within seven passages. Most tumor cells were positive for glial fibrillary acidic protein by immunohistochemical methods.

\section{Induction of LAK cells}

LAK cells were induced as described elsewhere. ${ }^{15}$ Briefly, PBMC were collected from the heparinized peripheral blood of normal healthy donors or patients with gliomas by centrifugation on a FicollPaque (Pharmacia Fine Chemicals, Uppsala, Sweden) density gradient. PBMC were cultured at $1-2 \times$ $10^{6} / \mathrm{ml}$ in RPMI 1640 medium containing $5 \%$ heatinactivated fresh frozen plasma (ABO blood type matched) and 3-6 U/ml of IL-2 (Takeda Pharmaceutical Co., Ltd., Osaka). After culturing for 3-5 days, LAK cells were collected.

\section{Tumor cell culture with LAK cells or PBMC}

LAK cells or PBMC were adjusted to a concentration of $2 \times 10^{6}$ cells $/ \mathrm{ml}$ in complete medium containing 5\% fresh frozen plasma and incubated with T98G, Daudi, or $\mathrm{K} 562$ cells at a LAK or PBMC/ tumor ratio of $10 / 1$ at $37^{\circ} \mathrm{C}$ under a $5 \% \mathrm{CO}_{2}$ atmosphere for 4,16 , or 40 hours in 24-well plates (Nunc, Roskilde, Denmark). After culture, the supernatants were harvested and stored at $-80^{\circ} \mathrm{C}$ until use. Preliminary studies indicated that this LAK/ tumor ratio was optimum for LAK cells to secrete TNF and LT.

\section{Measurement of TNF activity}

The assay for TNF activity in culture supernatants was a modification of procedures described previous- ly. ${ }^{11)}$ Serial two-fold dilutions of cell-free supernatant fluids from the LAK or PBMC/tumor cultures were added to $5 \times 10^{4} \mathrm{~L} . \mathrm{P} 3$ cells per well in 96-well flat-bottomed microtiter plates (Becton Dickinson and Co., Lincoln Park, N.J., U.S.A.) in the presence of $1 \mu \mathrm{g} / \mathrm{ml}$ actinomycin D (Sigma Chemical Co., St. Louis, Mo., U.S.A.). After 12-16-hour incubation at $37^{\circ} \mathrm{C}$, plates were stained with $0.5 \%$ crystal violet in $20 \%$ methanol for 5 minutes and washed thoroughly. The dye was dissolved in $50 \%$ ethanol and plates were read on a Titertek Multiskan (Flow Laboratories Inc., Helsinki, Finland). The activity of TNF (in $\mathrm{U} / \mathrm{ml}$ ) was defined as the reciprocal of the dilution causing lysis of $50 \%$ of the cells. The reproducibility of this assay demonstrated a coefficient of variation between assays of $23.6-30.9 \%$ depending on dilution.

\section{Neutralization test}

L.P3 cells are sensitive to both TNF and LT. To measure the specificity, the cell-free supernatants were separately incubated with anti-TNF $\left(1.5 \times 10^{5}\right.$ neutralizing $\mathrm{U} / \mathrm{ml}$ ) (donated by Dr. Ohshima, Teikyo Univ. School of Medicine, Tokyo), anti-LT $\left(3.2 \times 10^{4}\right.$ neutralizing $\mathrm{U} / \mathrm{ml}$ ) (donated by Dr. Niki, Mitsubishi Chemical Industry, Yokohama), or both antibodies for 1 hour at $37^{\circ} \mathrm{C}$ before testing in the $\mathrm{L}$ cell cytotoxic assay. The cross-reactivity of the antibodies was tested in the $\mathrm{L}$ cell cytotoxic assay. The antibodies were not cross-reactive, as anti-TNF antibody did not neutralize LT from the RPMI 1788 cell line and vice versa.

\section{Monocyte depletion from PBMC}

Monocytes have been shown to produce TNF. ${ }^{3)}$ To examine how the depletion of monocytes affects the secretion of TNF from PBMC cultured with tumor cells, monocytes were depleted from PBMC by plastic adherence.

PBMC were cultured in tissue culture flasks (Becton Dickinson and Co.) for 45 minutes at $37^{\circ} \mathrm{C}$ under $5 \% \mathrm{CO}_{2}$. The non-adherent cells were collected and cultured again. The non-adherent cells were collected and cultured with Daudi cells or singly. After 16 and 40 hours, the supernatants were harvested and TNF activity was tested.

\section{Flow cytometer}

The monocyte content in LAK cells after harvesting or that in PBMC after adherent cell depletion was analyzed by a flow cytometer (EPICS 751, Coulter Co., Hialeah, Fla., U.S.A.). Adherent celldepleted PBMC or LAK cells were incubated with $\mathrm{BALB} / \mathrm{c}$ mouse immunoglobulin $(1 \mathrm{mg} / \mathrm{ml})$ for 40 

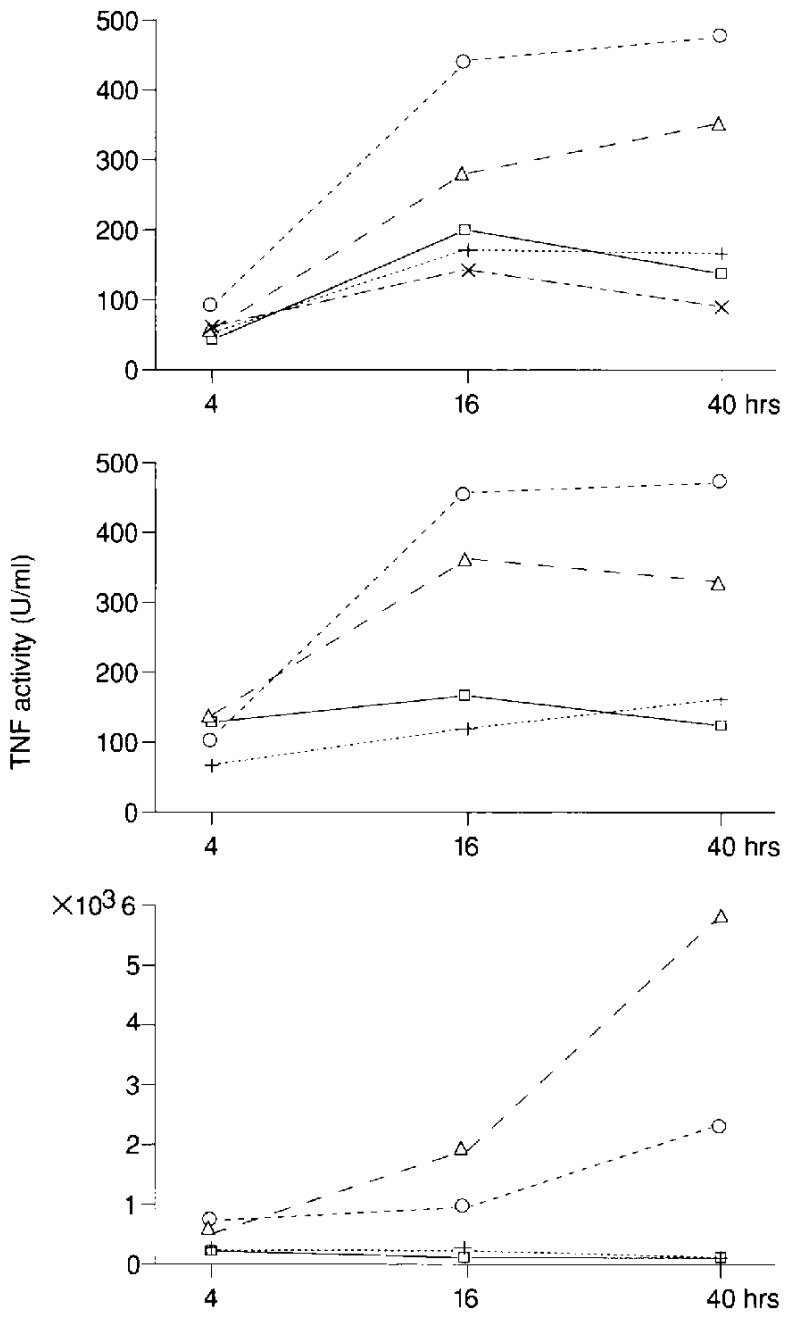

Fig. 1 Supernatant TNF activity from cultures of LAK cells only $(\square)$, and LAK cells with T98G $(+)$, A172 ( $X$ ), Daudi $(O)$, and K562 cells $(\triangle)$. upper: normal healthy donor, middle: patient with anaplastic astrocytoma, lower: patient with glioblastoma.

minutes at $4^{\circ} \mathrm{C}$. After washing, they were incubated with fluorescein isothiocyanate-labeled Leu-M3 monoclonal antibody (Becton Dickinson and Co.) for 40 minutes at $4^{\circ} \mathrm{C}$. After washing, the monocyte content was analyzed.

\section{Results}

\section{TNF and LT secretion from LAK cells}

LAK cells induced from PBMC of normal healthy donors or patients with astrocytoma were cultured singly or with T98G, A172, Daudi, or K562 cells. In one experiment, LAK cells were cultured with autologous anaplastic astrocytoma cells. Super- natants after culturing for 4,16 , or 40 hours were harvested and the TNF activity was measured.

The LAK culture supernatants showed weak TNF activity (34-128 U/ml at $4 \mathrm{hrs}$ ) at least after 4 hours of culture (Fig. 1). Increased supernatant TNF activity was seen when LAK cells were cultured with Daudi or K562 cells. LAK/T98G and LAK/A172 supernatant activity, however, was almost the same as that of LAK cells only. The culture supernatants from LAK/autologous anaplastic astrocytoma cells showed weak TNF activity $(62 \mathrm{U} / \mathrm{ml}$ at $4 \mathrm{hrs}$ and 88 $\mathrm{U} / \mathrm{ml}$ at $16 \mathrm{hrs}$ ), higher than that of LAK cells only and lower than that of LAK/Daudi cells at 16 hours (Fig. 2). The activity, however, decreased to a level lower than that of LAK cells only after culturing for 40 hours. The supernatants from T98G, Daudi, K562, and autologous tumor cells had no TNF activity.

The supernatant TNF activities from LAK cells only and from LAK/tumor cells were not neutralized by either anti-TNF or anti-LT antibody, but were neutralized completely by a combination of both antibodies (Table 1). Flow cytometry analysis found less than $0.5 \%$ Leu-M3 antibody positive monocytes in LAK cells harvested from culture flasks.

\section{TNF secretion from PBMC}

PBMC were cultured singly or with T98G, Daudi, or K562 cells. In some experiments, PBMC were cultured with autologous glioma cells. Supernatants after 4,16 , and 40 hours were harvested and the TNF activity on L.P3 cells was measured.

Low TNF activity levels $(2-25 \mathrm{U} / \mathrm{ml})$ were observed when PBMC only were cultured (Table 2). Co-culture of PBMC and Daudi or K562 cells resulted in increased TNF activity. Increased TNF ac-

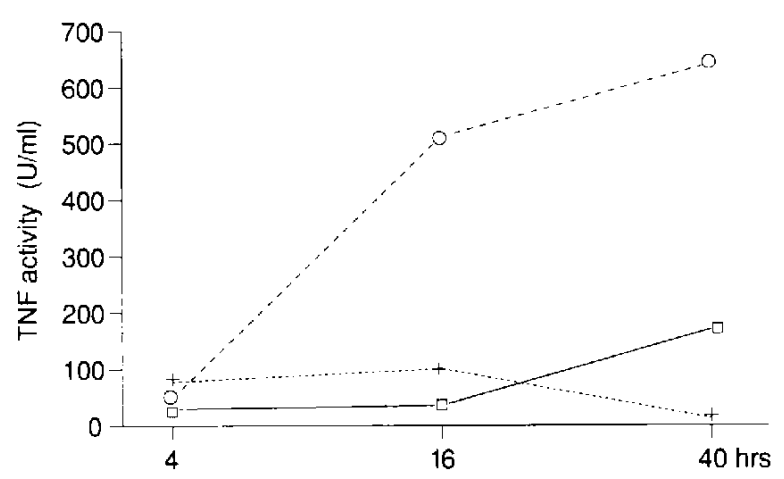

Fig. 2 Supernatant TNF activity from cultures of LAK cells only ( $\square)$, and LAK cells with autologous anaplastic astrocytoma $(+)$ and Daudi cells (O). 
Table 1 Neutralization test by anti-TNF and anti-LT antibodies in $\mathrm{L}$ cell cytotoxic assay

\begin{tabular}{|c|c|c|c|c|c|c|}
\hline \multirow[b]{2}{*}{ Supernatant } & \multirow[b]{2}{*}{ Donor* } & \multirow[b]{2}{*}{ Time $^{* *}$} & \multicolumn{4}{|c|}{ Cytotoxic activity $(\mathrm{U} / \mathrm{ml})$} \\
\hline & & & PBS & $\begin{array}{l}\text { Anti- } \\
\text { TNF }\end{array}$ & $\underset{\text { LT }}{\text { Anti- }}$ & $\begin{array}{c}\text { Anti-TNF } \\
\text { LT }\end{array}$ \\
\hline \multirow[t]{2}{*}{ PBMC only } & Al & $16 \mathrm{hrs}$ & 198 & $<8$ & 203 & $<4$ \\
\hline & $\mathrm{A} 2$ & $16 \mathrm{hrs}$ & 16 & $<8$ & 8 & $<4$ \\
\hline \multirow[t]{2}{*}{ PBMC/Daudi } & A3 & $\begin{array}{l}16 \mathrm{hrs} \\
40 \mathrm{hrs}\end{array}$ & $\begin{array}{l}489 \\
128\end{array}$ & $\begin{array}{l}<8 \\
<8\end{array}$ & $\begin{array}{l}394 \\
239\end{array}$ & $\begin{array}{l}<4 \\
<4\end{array}$ \\
\hline & A4 & $\begin{array}{l}16 \mathrm{hrs} \\
40 \mathrm{hrs}\end{array}$ & $\begin{array}{l}26 \\
64\end{array}$ & $\begin{array}{l}<8 \\
<8\end{array}$ & $\begin{array}{r}32 \\
104\end{array}$ & $\begin{array}{l}<4 \\
<4\end{array}$ \\
\hline $\begin{array}{l}\text { PBMC/ } \\
\text { autologous } \\
\text { tumor }\end{array}$ & B 1 & $16 \mathrm{hrs}$ & 336 & $<8$ & 322 & - \\
\hline \multirow[t]{2}{*}{ LAK only } & $\mathrm{B} 2$ & 3 days & 16 & 8 & 14 & $<4$ \\
\hline & B3 & 4 days & 17 & 15 & $<8$ & $<4$ \\
\hline \multirow[t]{3}{*}{ LAK/Daudi } & Al & $\begin{array}{l}16 \mathrm{hrs} \\
40 \mathrm{hrs}\end{array}$ & $\begin{array}{l}459 \\
351\end{array}$ & $\begin{array}{l}437 \\
352\end{array}$ & $\begin{array}{l}54 \\
12\end{array}$ & $\begin{array}{l}<4 \\
<4\end{array}$ \\
\hline & B2 & $\begin{array}{l}16 \mathrm{hrs} \\
40 \mathrm{hrs}\end{array}$ & $\begin{array}{l}445 \\
327\end{array}$ & $\begin{array}{r}75 \\
160\end{array}$ & $\begin{array}{l}361 \\
130\end{array}$ & $\begin{array}{r}<4 \\
7\end{array}$ \\
\hline & B3 & $16 \mathrm{hrs}$ & 253 & 56 & 223 & - \\
\hline $\begin{array}{l}\text { LAK/ } \\
\text { autologous } \\
\text { tumor }\end{array}$ & B3 & 16 hrs & 101 & 17 & 80 & $<4$ \\
\hline
\end{tabular}

*A1-4: normal healthy donors, B1-3: patients with malignant or low-grade astrocytoma. ${ }^{* *}$ Duration of culture of PBMC or LAK cells. PBS: phosphate buffered saline.

tivity was not observed in supernatants from PBMC/T98G. TNF activity from PBMC/ autologous tumor cells was lower than that of PBMC/Daudi (Table 3).

We examined the TNF activity of supernatants from co-culture of Daudi cells and PBMC with or without adherent mononuclear cell depletion. Flow cytometry analysis showed that the monocyte content was less than $0.8 \%$ after adherent mononuclear cell depletion twice. The supernatant TNF activity from an adherent cell-depleted PBMC/Daudi culture was less than $5.3 \%$ of an undepleted PBMC/ Daudi culture (Table 4).

Anti-TNF antibody completely neutralized TNF activity in supernatants from PBMC only and PBMC/tumor cells (Table 1).

\section{Discussion}

The present study shows that malignant glioma cells failed to stimulate cytokine secretion in LAK cells and PBMC, although the tumor cells can be killed by LAK cells. LAK cells, however, produced both TNF and $\mathrm{LT}$ in vitro on stimulation with non-gliomatous tumor cell lines. The TNF release from LAK cells did not originate from monocytes. PBMC cultured with allogeneic non-gliomatous tumor cell lines secreted
Table 2 Supernatant TNF activity from cultures of PBMC with T98G, Daudi, or K562 cells

\begin{tabular}{cccccc}
\hline \multirow{2}{*}{ Donor* } & & \multicolumn{4}{c}{ TNF activity (U/ml) } \\
\cline { 3 - 6 } & $\begin{array}{c}\text { Time } \\
\text { (hrs) }\end{array}$ & $\begin{array}{c}\text { PBMC } \\
\text { only }\end{array}$ & $\begin{array}{c}\text { PBMC/ } \\
\text { T98G }\end{array}$ & $\begin{array}{c}\text { PBMC/ } \\
\text { Daudi }\end{array}$ & $\begin{array}{c}\text { PBMC/ } \\
\text { K562 }\end{array}$ \\
\hline \multirow{2}{*}{1} & 4 & 5 & 25 & 65 & 35 \\
& 16 & 25 & 25 & 309 & 182 \\
& 40 & 2 & 4 & 122 & 46 \\
2 & 4 & 4 & 5 & 15 & 13 \\
& 16 & 5 & 4 & 8 & 6 \\
3 & 40 & 2 & 2 & 54 & 7 \\
& 4 & 7 & 10 & 19 & 12 \\
& 16 & 2 & 3 & 13 & 18 \\
& 40 & 3 & 3 & 27 & 7 \\
\hline
\end{tabular}

*Normal healthy donors.

Table 3 Supernatant TNF activity from cultures of PBMC with autologous tumor cells or Daudi cells

\begin{tabular}{ccccc}
\hline \multirow{2}{*}{ Donor* } & & \multicolumn{3}{c}{ TNF activity (U/ml) } \\
\cline { 4 - 5 } & $\begin{array}{l}\text { Time } \\
\text { (hrs) }\end{array}$ & $\begin{array}{c}\text { PBMC } \\
\text { only }\end{array}$ & $\begin{array}{c}\text { PBMC/ } \\
\text { autologous tumor }\end{array}$ & $\begin{array}{c}\text { PBMC/ } \\
\text { Daudi }\end{array}$ \\
\hline \multirow{2}{*}{1} & 4 & 2 & 4 & 144 \\
& 16 & 6 & 21 & 862 \\
& 40 & 3 & 115 & 72 \\
2 & 4 & 12 & 92 & 425 \\
& 16 & 6 & 77 & 1657 \\
\hline
\end{tabular}

*1: patient with anaplastic astrocytoma, 2: patient with astrocytoma grade II.

Table 4 Supernatant TNF activity from a co-culture of Daudi cells and PBMC with or without adherent mononuclear cell depletion

\begin{tabular}{|c|c|c|c|c|c|}
\hline \multirow[b]{2}{*}{ Donor* } & \multirow[b]{2}{*}{$\begin{array}{l}\text { Time } \\
\text { (hrs) }\end{array}$} & \multicolumn{4}{|c|}{ TNF activity $(\mathrm{U} / \mathrm{ml})$} \\
\hline & & $\begin{array}{c}\text { PBMC } \\
\text { only }\end{array}$ & $\begin{array}{c}\text { Non- } \\
\text { adherent } \\
\text { PBMC }\end{array}$ & $\begin{array}{c}\text { PBMC/ } \\
\text { Daudi }\end{array}$ & $\begin{array}{c}\text { Non- } \\
\text { adherent } \\
\text { PBMC/ } \\
\text { Daudi }\end{array}$ \\
\hline 1 & $\begin{array}{l}16 \\
40\end{array}$ & $\begin{array}{l}96 \\
32\end{array}$ & $\begin{array}{r}4 \\
<2\end{array}$ & $\begin{array}{l}970 \\
467\end{array}$ & $\begin{array}{l}24 \\
19\end{array}$ \\
\hline 2 & $\begin{array}{l}16 \\
40\end{array}$ & - & $\begin{array}{r}3 \\
<2\end{array}$ & $\begin{array}{l}681 \\
512\end{array}$ & $\begin{array}{l}36 \\
23\end{array}$ \\
\hline
\end{tabular}

*Normal healthy donors.

only TNF mainly in monocytes. TNF secretion in PBMC was also minimal by culture with glioma cells. This indicates the discrepancy between the capability of LAK cell lysis of malignant glioma cells and the secretion of TNF and LT from LAK cells. 
Like natural killer cells, ${ }^{28)}$ the lytic sequence by LAK cells can be divided into 1) the binding stage, 2) the "programming for lysis" stage, 3) secretion of lytic factors, and 4) the killer cell-independent phase of lysis. After binding to tumor cells, LAK cells may recognize some unknown molecules on targets and "programming for cytokine secretion" may occur as well as "programming for lysis." Malignant glioma cells may affect this step. Since all LAK cells do not bind to tumor cells, ${ }^{22)}$ unbound LAK cells might be able to secrete cytokines. This may be the reason why cytokine contents in the supernatants from LAK/T98G remained at base line level.

PBMC are known to secrete TNF, LT, and/or IFN- $\gamma$ under stimulation from IL-2, mitogen, OKT3 antibody, phorbol ester, or calcium ionophore. ${ }^{6,24,26,32,35,36)}$ Thus, LAK cells are the potential secretor of TNF, LT, and IFN- $\gamma$. In contrast to our results, previous reports have shown that tumor targets (leukemia, lymphoma, and breast carcinoma cell lines) stimulate LAK cells to produce TNF and IFN $-\gamma,{ }^{5)}$ and that TNF, LT, and IFN- $\gamma$ are present in the sera of IL-2/LAK-treated patients with melanoma, renal cell carcinoma, or colon carcinoma as well as in vitro by stimulation with tumor cell lines (Daudi and colon carcinoma). ${ }^{13)}$

The reason why malignant glioma cells do not stimulate cytokine secretion from LAK cells or PBMC is unknown. One possibility is that malignant glioma cells may secrete a factor which inhibits cytokine release from LAK cells. Human glioblastoma cells are known to secrete factors, such as transforming growth factor (TGF)- $\beta 2$ and prostaglandin $\mathrm{E}$, capable of suppressing several immune functions. ${ }^{4,7,12,37)}$ TGF- $\beta 2$ has been isolated from the conditioned medium of a human glioblastoma cell line and is known to share $71 \%$ amino acid homology with TGF- $\beta 1,{ }^{7,37}$ which has an inhibitory effect on cytokine production and LAK activity. ${ }^{9,10}$ TGF$\beta 2$ also suppresses IL-2-induced LAK activity, ${ }^{9.20}$ but how it affects cytokine secretion from lymphocytes is not known.

Recently, synergistic effects among cytokines have been reported. TNF and IFN- $\gamma$ act synergistically to achieve a cytostatic or cytolytic effect on some tumor cells $^{34)}$ and induce class I and II human leukocyte antigen gene expression which might provoke tumor rejection by induction of tumor-specific immune responses. ${ }^{27)} \mathrm{IFN}-\gamma$ and $\mathrm{LT}$ act synergistically to inhibit the proliferation of neoplastic cells, ${ }^{21)}$ and TNF or LT is synergistic with IFN- $\gamma$ in the induction of tumoricidal murine macrophages. ${ }^{8)}$ Thus, IFN- $\gamma$, TNF, and LT are important in synergistic cytotoxic or cytostatic effects on tumor cells. Malignant glioma cells, however, seem to suppress the secretion of cytotoxic cytokines from LAK cells or PBMC.

In conclusion, non-gliomatous tumor cells stimulated LAK cells to secrete TNF and LT, but glioblastoma cells failed to stimulate cytokine secretion. We suggest that malignant glioma cells produce some factors which inhibit cytokine secretion from LAK cells. This may decrease the effectiveness of LAK cell therapy for patients with malignant glioma. We need to investigate the reason why malignant glioma cells fail to stimulate LAK cells or PBMC to secrete cytokines.

\section{Acknowledgment}

The authors acknowledge the secretarial assistance of Miss Yuko Nakamura.

This work was supported in part by a Project Research Grant from Yamanashi Medical College.

\section{References}

1) Aggarwal BB, Moffat B, Harkins RN: Human lymphotoxin. Production by a lymphoblastoid cell line, purification, and initial characterization. $J$ Biol Chem 259: 686-691, 1984

2) Beutler B, Cerami A: Cachectin and tumour necrosis factor as two sides of the same biological coin. Nature 320: 584-588, 1986

3) Carswell EA, Old LJ, Kassel RL, Green S, Fiore N, Williamson B: An endotoxin-induced serum factor that causes necrosis of tumors. Proc Natl Acad Sci USA 72: 3666-3670, 1975

4) Castelli MG, Chiabrando C, Fanelli R, Martelli L, Butti G, Gaetani P, Paoletti P: Prostaglandin and thromboxane synthesis by human intracranial tumors. Cancer Res 49: 1505-1508, 1989

5) Chong ASF, Scuderi $P$, Grimes WT, Hersh EM: Tumor targets stimulate IL-2 activated killer cells to produce interferon- $\gamma$ and tumor necrosis factor. $J \mathrm{Im}$ munol 142: 2133-2139, 1989

6) Cuturi MC, Murphy M, Costa-Giomi MP, Weinmann R, Perussia B, Trinchieri G: Independent regulation of tumor necrosis factor and lymphotoxin production by human peripheral blood lymphocytes. J Exp Med 165: 1581-1594, 1987

7) de Martin R, Haendler B, Hofer-Warbinek R, Gaugitsch H, Wrann M, Schlusener H, Seifert JM, Bodmer S, Fontana A, Hofer E: Complementary DNA for human glioblastoma-derived $T$ cell suppressor factor, a novel member of the transforming growth factor- $\beta$ gene family. EMBO J 6: 3673-3677, 1987

8) Esparza I, Mannel D, Ruppel A, Falk W, Krammer PH: Interferon and lymphotoxin or tumor necrosis 
factor act synergistically to induce macrophage killing of tumor cells and schistosomula of Schistoma mansoni. J Exp Med 166: 589-594, 1987

9) Espevik T, Figari IS, Ranges GE, Palladino MA: Transforming growth factor $\beta 1 \quad(\mathrm{TGF}-\beta 1)$ and recombinant human tumor necrosis factor- $\alpha$ reciprocally regulate the generation of lymphokine-activated killer cell activity. Comparison between natural porcine platelet-derived TGF- $\beta 1$ and TGF- $\beta$ 2 , and recombinant human TGF- $\beta$ 1. J Immunol 140: 2312-2316, 1988

10) Espevik T, Figari IS, Shalaby MR, Lackides GA, Lewis GD, Shepard HM, Palladino MA: Inhibition of cytokine production by cyclosporine $\mathrm{A}$ and transforming growth factor. $J$ Exp Med 166: 571576,1987

11) Flick DA, Gifford GE: Comparison of in vitro cell cytotoxic assays for tumor necrosis factor. $J \mathrm{Im}$ munol Methods 68: 167-175, 1984

12) Fontana A, Kristensen F, Dubs R, Gemsa D, Weber $\mathrm{E}$ : Production of prostaglandin $\mathrm{E}$ and an interleukin 1-like factor by cultured astrocytes and C6 glioma cells. J Immunol 129: 2413-2419, 1982

13) Gemlo BT, Palladino MA, Jaffe HS, Espevik TP, Rayner AA: Circulating cytokines in patients with metastatic cancer treated with recombinant interleukin 2 and lymphokine-activated killer cells. Cancer Res 48: 5864-5867, 1988

14) Grimm EA, Mazumder A, Zhang HZ, Rosenberg SA: Lymphokine-activated killer cell phenomenon. Lysis of natural killer-resistant fresh solid tumor cells by interleukin 2 activated autologous human peripheral blood lymphocytes. J Exp Med 155: 18231841,1982

15) Iizuka $H$, Naganuma $H$, Yabusaki $N$, Komatsu $H$, Sakihama T, Iimuro $Y$, Yamamoto $Y$, Fujii $H$, Yamamoto M, Matsumoto $Y$, Sugahara K, Nukui $H$, Ueno A, Nakajima Y, Tasaka K: Study on lymphokine activated killer (LAK) cells. I. Improved LAK cell induction in vitro. Yamanashi Ika Daigaku Zasshi 3: 97-103, 1988

16) Jacobs SK, Wilson DJ, Kornblith PL, Grimm EA: Interleukin-2 or autologous lymphokine-activated killer cell treatment of malignant glioma: Phase I trial. Cancer Res 46: 2101-2104, 1986

17) Jacobs SK, Wilson DJ, Kornblith PL, Grimm EA: Interleukin-2 and autologous lymphokine-activated killer cells in the treatment of malignant glioma. Preliminary report. $J$ Neurosurg 64: 743-749, 1986

18) Jacobs SK, Wilson DJ, Melin G, Parham CW, Holcomb B, Kornblith PL, Grimm EA: Interleukin-2 and lymphokine-activated killer (LAK) cells in the treatment of malignant glioma: Clinical and experimental studies. Neurol Res 8: 81-87, 1986

19) Kovacs EJ, Beckner SK, Longo DL, Varesio L, Young HA: Cytokine gene expression during the generation of human lymphokine-activated killer cells: Early induction of interleukin 1 by interleukin 2. Cancer Res 49: 940-944, 1989
20) Kuppner MC, Hamou MF, Bodmer S, Fontana A, de Tribolet N: The glioblastoma derived $T$ cell suppressor factor/transforming growth factor beta 2 inhibits the generation of lymphokine activated killer (LAK) cells. Int $J$ Cancer 42: 562-567, 1988

21) Lee SH, Aggarwal BB, Rinderknecht E, Assisi F, Chiu $\mathrm{H}$ : The synergistic anti-proliferative effect of $\gamma$ interferon and human lymphotoxin. I Immunol 133: 1083-1086, 1984

22) Naganuma $H$, Kiessling $R$, Patarroyo $M$, Hansson M, Handgretinger R, Grönberg A: Increased susceptibility of IFN- $\boldsymbol{\gamma}$-treated neuroblastoma cells to lysis by lymphokine activated killer cells: Participation of ICAM-1 induction on target cells. Int $J$ Cancer 47: $527-532,1991$

23) Naganuma H, Kimura R, Sasaki A, Fukamachi A, Nukui $\mathbf{H}$, Tasaka K: Complete remission of recurrent glioblastoma multiforme following infusions of lymphokine activated killer cells. Case report. Acta Neurochir (Wien) 99: 157-160, 1989

24) Nedwin GE, Svedersky LP, Bringman TS, Palladino MA, Goeddel DV: Effect of interleukin 2, interferon$\gamma$, and mitogens on the production of tumor necrosis factor $\alpha$ and $\beta . J$ Immunol 135: 2492-2497, 1985

25) Old LJ: Tumor necrosis factor (TNF). Science 230 : 630-632, 1985

26) Paya CV, Kenmothu N, Schoon RA, Leibson PJ: Tumor necrosis factor and lymphotoxin secretion by human natural killer cells leads to antiviral cytotoxicity. J Immunol 141: 1989-1995, 1988

27) Pfizenmaier K, Scheurich $P$, Schluter $C$, Kronke M: Tumor necrosis factor enhances HLA-A, B, C and HLA-DR gene expression in human tumor cells. $J \mathrm{Im}$ munol 138: 975-980, 1987

28) Roder JC, Kiessling R, Biberfeld P, Andersson B: Target-effector interaction in the natural killer (NK) cell system. II. The isolation of NK cells and studies on the mechanism of killing. $J$ Immunol 121: 25092517,1978

29) Rosenberg SA, Lotze MT, Muul LM, Chang AE, Avis FP, Leitman S, Linehan M, Robertson CN, Lee RE, Rubin JT, Seipp CA, Simpson CG, White DE: A progress report on the treatment of 157 patients with advanced cancer using lymphokine-activated killer cells and interleukin-2 or high dose IL-2. $N$ Engl $J$ Med 316: 889-897, 1987

30) Rosenberg SA, Lotze MT, Muul LM, Leitman S, Chang AE, Ettinghausen SE, Matory YL, Skibber JM, Shiloni E, Vetto JT, Seipp CA, Simpson C, Reichert CM: Observations on the systemic administration of autologous lymphokine-activated killer cells and recombinant interleukin-2 to patients with metastatic cancer. $N$ Engl $J$ Med 313: 14851492,1985

31) Shimizu K, Okamoto $Y$, Miyao $Y$, Yamada M, Ushio $Y$, Hayakawa T, Ikeda $H$, Mogami H: Adoptive immunotherapy of human meningeal gliomatosis and carcinomatosis with LAK cells and recombinant interleukin-2. J Neurosurg 66: 519-521, 1987 
32) Steffen M, Ottmann OG, Moore MAS: Simultaneous production of tumor necrosis factor- $\alpha$ and $1 \mathrm{ym}$ photoxin by normal T cells after induction with IL-2 and anti-T3. J Immunol 140: 2621-2624, 1988

33) Stone-Wolff DS, Yip YK, Kelker HC, Le J, Henriksen-Destefano D, Rubin BY, Rinderknecht E, Aggarwal BB, Vilcek J: interrelationships of human interferon-gamma with lymphotoxin and monocyte cytotoxin. J Exp Med 159: 828-843, 1984

34) Sugarman BJ, Aggarwal BB, Hass PE, Figari IS, Palladino MA, Shepard HM: Recombinant human tumor necrosis factor- $\alpha$ : Effects on proliferation of normal and transformed cells in vitro. Science 230. 943-945, 1985

35) Svedersky LP, Nedwin GE, Goeddel DV, Palladino MA: Interferon- $\gamma$ enhances induction of lymphotoxin in recombinant interleukin 2-stimulated peripheral blood mononuclear cells. J Immunol 134: 1604-1608, 1985

36) Turner M, Londei M, Feldmann M: Human $T$ cells from autoimmune and normal individuals can produce tumor necrosis factor. Eur J Immunol 17: 18071814,1987

37) Wrann M, Bodmer S, de Martin R, Siepl C, HoferWarbinek R, Frei K, Hofer E, Fontana A: T cell suppressor factor from human glioblastoma cells is a 12.5 -kd protein closely related to transforming growth factor- $\beta$. EMBO $J 6: 1633-1636,1987$

38) Yoshida S, Tanaka R, Takai N, Ono K: Local administration of autologous lymphokine-activated killer cells and recombinant interleukin 2 to patients with malignant brain tumors. Cancer Res 48: 50115016,1988

Address reprint requests to: H. Naganuma, M.D., Department of Neurosurgery, Yamanashi Medical College, 1110 Shimokato, Tamaho-machi, Nakakoma-gun, Yamanashi 409-38, Japan. 